\title{
Laboratory Study on Regeneration of Spent DOWEX 21K 16-20 Mesh lon Exchange Resin
}

J. B. Duncan

CH2M HILL Hanford Group, Inc.

Richland, WA 99352

U.S. Department of Energy Contract DE-AC27-99RL14047

$\begin{array}{lll}\text { EDT/ECN: } & \text { DRF } & \text { UC: } \\ \text { Cost Center: } & 7 \text { S1 } 10 & \text { Charge Code: } \\ \text { B\&R Code: } & & \text { Total Pages: } 12\end{array}$

Key Words: Effluent Treatment Facility, sodium hydroxide, sulfuric acid, $100 \mathrm{~K}, 100 \mathrm{H}, \mathrm{KR}-4$, analysis, DOWEX $21 \mathrm{~K}$, spent resin, regeneration, solutions, chromium, groundwater, elution, Siemens, bed volumes, experiment, RPP-PLAN-31627

Abstract: Currently the effort to remove chromate from groundwater in the $100 \mathrm{~K}$ and $100 \mathrm{H}$ Areas uses DOWEX $21 \mathrm{~K} 16-20$. This report addresses the procedure and results of a laboratory study for regeneration of the spent. resin by sodium hydroxide, sulfuric acid, or sodium sulfate to determine if onsite regeneration by the Effluent Treatment Facility is a feasible option.

TRADEMARK DISCLAIMER. Reference herein to any specific commercial product, process, or service by trade name, trademark, manufacturer, or otherwise, does not necessarily constitute or imply its endorsement, recommendation, or favoring by the United States Government or any agency thereof or its contractors or subcontractors.

Printed in the United States of America. To obtain copies of this document, contact: Document Control Services, P.O. Box 950, Mailstop H6-08, Richland WA 99352, Phone (509) 372-2420; Fax (509) 376-4989.

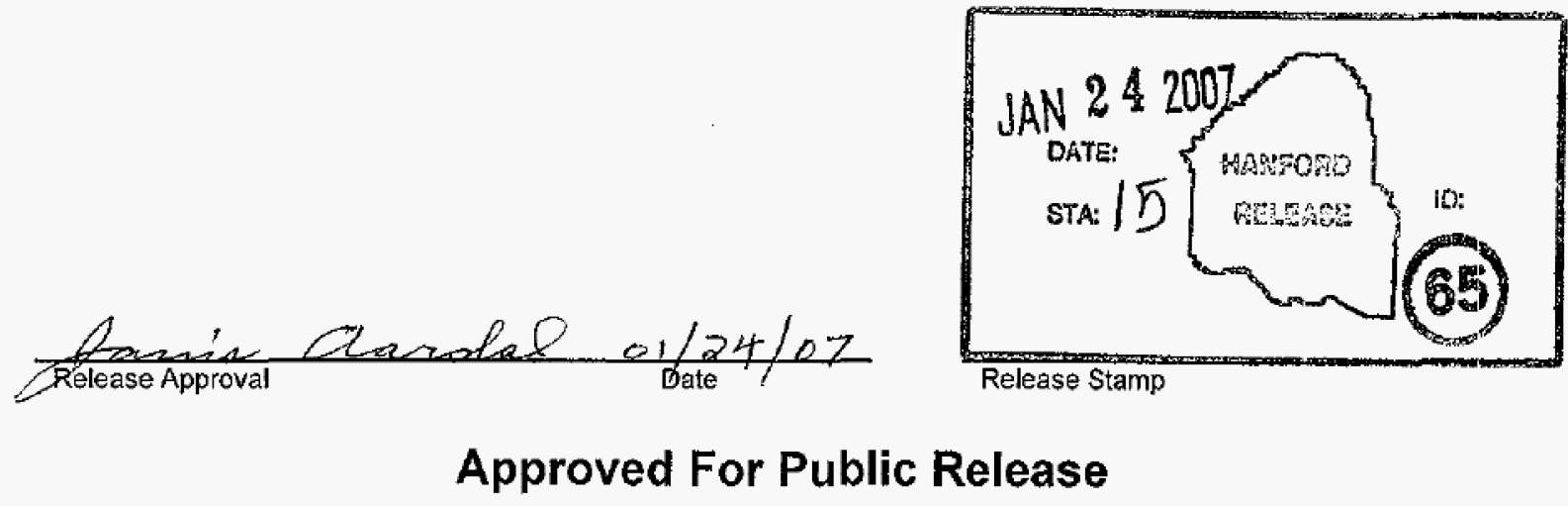


RPP-RPT-32207

Revision 0

\section{Laboratory Study on Regeneration of Spent DOWEX 21K 16-20 Mesh Ion Exchange Resin}

\section{J. B. Duncan}

CH2M HILL Hanford Group, Inc.

Date Published

January 2007

\section{CM2MHILL \\ Hanford Group, inc.}

Prepared for the U.S. Department of Energy

Office of River Protection

Contract No. DE-AC27-99RL14047

Approved for public release; distribution is unlimited 
RPP-RPT-32207, Rev. 0

\section{CONTENTS}

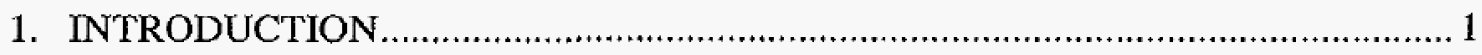

2. PROCEDURE AND RESULTS .................................................................... 1

2.1. Sodium Hydroxide Regeneration Tests....................................................... 2

2.2 Sulfuric Acid Regeneration Tests ........................................................ 2

2.3 Sodium Sulfate Regeneration Testing ................................................. 3

2.4 Sodium Sulfate Elution test.............................................................. 3

2.4.1 Comparison of Siemens and Sodium Sulfate Regenerated Resin ............... 4

2.4.2 Chromate Residual and Capacity of Sodium Sulfate Regenerated Resin...6

3. CONCLUSIONS AND RECOMMENDATIONS ........................................... 7

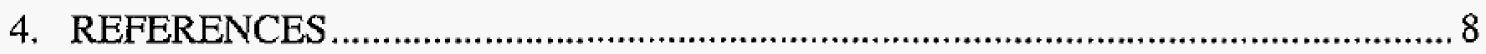




\section{INTRODUCTION}

Currently the pump and treat effort to remove chromate $[\mathrm{Cr}(\mathrm{VI})]$ from groundwater in the $\mathrm{K}$ and $\mathrm{H}$ areas located in the 100 Area of the Hanford Site uses DOWEX $21 \mathrm{~K}^{\mathrm{M}_{1}}$ 16-20 mesh anion exchange resin (hereinafter referred to as DOWEX 21K). The pump and treat unit is composed of four resin columns (approximately $80 \mathrm{ft}^{3}$ each); column 1 is a sacrificial column that is currently not regenerated (sent to burial), and columns 2, 3, and 4 are in a lead, lag, and polish configuration. The resin in columns 2, 3, and 4 is currently sent offsite to Minnesota for regeneration. The DOWEX $21 \mathrm{~K}$ is a Type I strong base anion exchange resin. The Type I resins have the following structure (Schweitzer 1997):

$$
\mathrm{R}-\mathrm{CH}_{2}-\mathrm{N}^{+}-\left(\mathrm{CH}_{3}\right) \mathrm{OH}^{-}
$$

According to the literature, ions of higher charge are preferentially exchanged over ions of lower charge, but there are exceptions. One example is the divalent $\mathrm{CrO}_{4}{ }^{-2}$ ion, which has a lower exchange preference than do the monovalent $\mathrm{I}^{-}$and $\mathrm{NO}_{3}{ }^{-}$ions (Weber 1972). However, Letterman (1999) states that $\mathrm{CrO}_{4}{ }^{-2}$ ion has a much higher affinity to resin than even $\mathrm{SO}_{4}{ }^{-2}$, and Lee and Lin (1999) report that the selectivity of the $\mathrm{CrO}_{4}{ }^{-2}$ ion over the $\mathrm{SO}_{4}{ }^{-2}$ ion is 10.98 times as great on a Type I strong base, $8 \%$ cross-linked anion exchange resin.

A portion of the spent resins are currently shipped offsite for regeneration. These resins are regenerated with a $10 \%$ sodium chloride solution. Regeneration with sodium chloride at the onsite facility [200 Area Effluent Treatment Facility (ETF)], is not possible due to concerns with corrosion of the stainless steel. The contradictory literature for chromate, sodium hydroxide, sulfuric acid, and sodium sulfate makes it necessary to conduct laboratory testing to determine a viable regeneration process for the spent resins.

This report is executed under RPP-PLAN-31627, Test Plan for the Regeneration of DOWEX $21 \mathrm{~K}$ I6-20 Mesh Anion Spent Resin for the Effluent Treatment Facility.

\section{PROCEDURE AND RESULTS}

This section describes the regeneration attempts with sodium hydroxide, sulfuric acid, and sodium sulfate. Initially, the number of bed volumes (BV) used to elute the resin were recommendations from the DOW Chemical Company. In all cases, the resin was sluiced into the column and allowed to settle. Water was drained so the meniscus was just touching the top of the resin column. The eluant would then be pumped into the column at the requisite flow rate. All chrome or sulfate results presented were accomplished using the $\mathrm{HACH} 8023^{2}$ method.

\footnotetext{
${ }^{1}$ DOWEX $^{7 \mathrm{M}}$ is a registered trademark of DOW Chemical Company, Midland, Michigan.

${ }^{2} \mathrm{HACH}$ is a trademark of HACH Company, Loveland, Colorado.
} 


\section{RPP-RPT-32207, Rev. 0}

\subsection{SODIUM HYDROXIDE REGENERATION TESTS}

A $10-\mathrm{mL}$ BV of spent resin supplied by Fluor Hanford, Inc. groundwater was used to test the efficacy of using a $4 \% \mathrm{NaOH}$ and a higher ionic strength of $10 \% \mathrm{NaOH}$ at a flow rate of $2 \mathrm{BV} / \mathrm{hr}$, downflow followed by a slow DI water rinse. Chrome(VI) concentration was determined at the end of $3 \mathrm{BV}$, followed by $30 \mathrm{BV}$ of $0.5 \mathrm{M}$ sodium sulfate to strip any remaining chromate from the resin. During the water rinse, $\mathrm{pH}$ was recorded up to the amount of $\mathrm{BV}$ that yielded a $\mathrm{pH}$ in the range of 7 to 8 . See Table 1 .

Table 1. Result of $\mathbf{4}$ and $\mathbf{1 0} \%$ Sodium Hydroxide Elution.

\begin{tabular}{|l|c|c|}
\hline \multicolumn{3}{|c|}{ BV $=10-\mathrm{mL}$ DOWEX 21K 16-20 } \\
\hline & $4 \%$ NaOH & $10 \%$ NaOH \\
\hline BV eluant & 3 & 3 \\
\hline $\mathrm{Cr}(\mathrm{VI}) \mathrm{mg} / \mathrm{L}$ & 2.6 & 10 \\
\hline $\mathrm{Cr}(\mathrm{VI}) \mathrm{mg}$ & 0.078 & 0.3 \\
\hline $\mathrm{BV}$ wash to $\mathrm{pH} 7-8$ & 5 & 9 \\
\hline $\mathrm{BV} \mathrm{Na} \mathrm{SO}_{4}$ & 30 & 30 \\
\hline $\mathrm{Cr}(\mathrm{VI}) \mathrm{mg} / \mathrm{L}$ & 4.3 & 5 \\
\hline $\mathrm{Cr}(\mathrm{VI}) \mathrm{mg}$ & 1.29 & 1.5 \\
\hline Total $\mathrm{Cr}(\mathrm{VI}), \mathrm{mg}$ Eluted & 1.37 & 1.8 \\
\hline
\end{tabular}

\subsection{SULFURIC ACID REGENERATION TESTS}

A $10-\mathrm{mL} \mathrm{BV} \mathrm{of} \mathrm{the} \mathrm{spent} \mathrm{resin} \mathrm{was} \mathrm{eluted} \mathrm{with} 4 \%$ sulfuric acid for 5 BV. Since the amount of $\mathrm{Cr}(\mathrm{VI})$ eluted from the column using sulfuric acid was negligible, it was decided to follow the sulfuric acid with a $4 \% \mathrm{NaOH}$ elution to convert the resin to the hydroxide after an acid wash as specified by DOW recommendations. See Table 2 .

Table 2. Result of the 4\% Sulfuric Acid and Sodium Hydroxide Elution.

\begin{tabular}{|c|c|c|}
\hline B V = & BL DOWEX & \\
\hline ry & $4 \% \mathrm{H}_{2} \mathrm{SO}_{4}$ & $4 \% \mathrm{NaOH}$ \\
\hline BV eluant & 5 & 2 \\
\hline $\mathrm{Cr}(\mathrm{VI}) \mathrm{mg} / \mathrm{L}$ & 0.25 & 5 \\
\hline $\mathrm{Cr}(\mathrm{VI}) \mathrm{mg}$ & 0.0125 & 0.1 \\
\hline BV DI water wash & 3 & \\
\hline 30 & ute $4 \% \mathrm{NaOH}$ & inse \\
\hline BV eluant & & 1 \\
\hline $\mathrm{Cr}(\mathrm{VI}) \mathrm{mg} / \mathrm{L}$ & & 2.5 \\
\hline $\mathrm{Cr}$ (VI) $\mathrm{mg}$ & & 0.025 \\
\hline M $\quad 0.51$ & $\mathrm{SO}_{4}$ & \\
\hline BV eluant & 30 & \\
\hline $\mathrm{Cr}(\mathrm{VI}) \mathrm{mg} / \mathrm{L}$ & 2.4 & \\
\hline $\mathrm{Cr}(\mathrm{VI}) \mathrm{mg}$ & 0.72 & \\
\hline Total Cr(VI), mg eluted & 0.86 & \\
\hline
\end{tabular}




\subsection{SODIUM SULFATE REGENERATION TESTING}

Since the literature has indicated that the chromate ion is preferred over the sulfate ion on Type I strong base anion exchange resins, it was decided to attempt a regeneration using an eluant of sodium sulfate. The first test carried out was an equilibrium of the spent resin against a control of deionized (DI) water and several molar concentrations of sodium sulfate. The results are presented in Table 3 . This data indicates that varying concentrations of sodium sulfate was effective. Based on this data a decision was made to conduct the remaining testing with $0.5 \mathrm{M}$ sodium sulfate. Additionally, this concentration of sodium sulfate can be produced at the 200 Area ETF.

Table 3. 0.5 M Sodium Sulfate Elution.

\begin{tabular}{|l|c|}
\hline \multicolumn{2}{|c|}{$\mathrm{Na}_{2} \mathrm{SO}_{4}$ Equilibrium } \\
\hline \multicolumn{1}{|c|}{ Eluant } & $\mathrm{Cr}(\mathrm{VI} / \mathrm{g}$ dry uesin (mg) \\
\hline $\mathrm{DI}$ water & $6.2 \mathrm{E}-04$ \\
\hline $0.3 \mathrm{M} \mathrm{Na}_{2} \mathrm{SO}_{4}$ & $3.5 \mathrm{E}-01$ \\
\hline $0.5 \mathrm{M} \mathrm{Na}_{2} \mathrm{SO}_{4}$ & $3.9 \mathrm{E}-01$ \\
\hline $0.7 \mathrm{M} \mathrm{Na}_{2} \mathrm{SO}_{4}$ & $4.4 \mathrm{E}-01$ \\
\hline $1.0 \mathrm{M} \mathrm{Na}_{2} \mathrm{SO}_{4}$ & $3.8 \mathrm{E}-01$ \\
\hline
\end{tabular}

\subsection{SODIUM SULFATE ELUTION TEST}

An experiment was carried out using $0.5 \mathrm{M}$ sodium sulfate against a $10-\mathrm{mL}$ resin $\mathrm{BV}$; the flow rate was at $1 \mathrm{BV} /$ hour, and samples were taken every $0.5 \mathrm{BV}$. The results are presented in Table 4 . The purpose of this test was to verify the capacity of the sodium sulfate to remove chromate.

Table 4. Elution Using 0.5 M Sodium Sulfate.

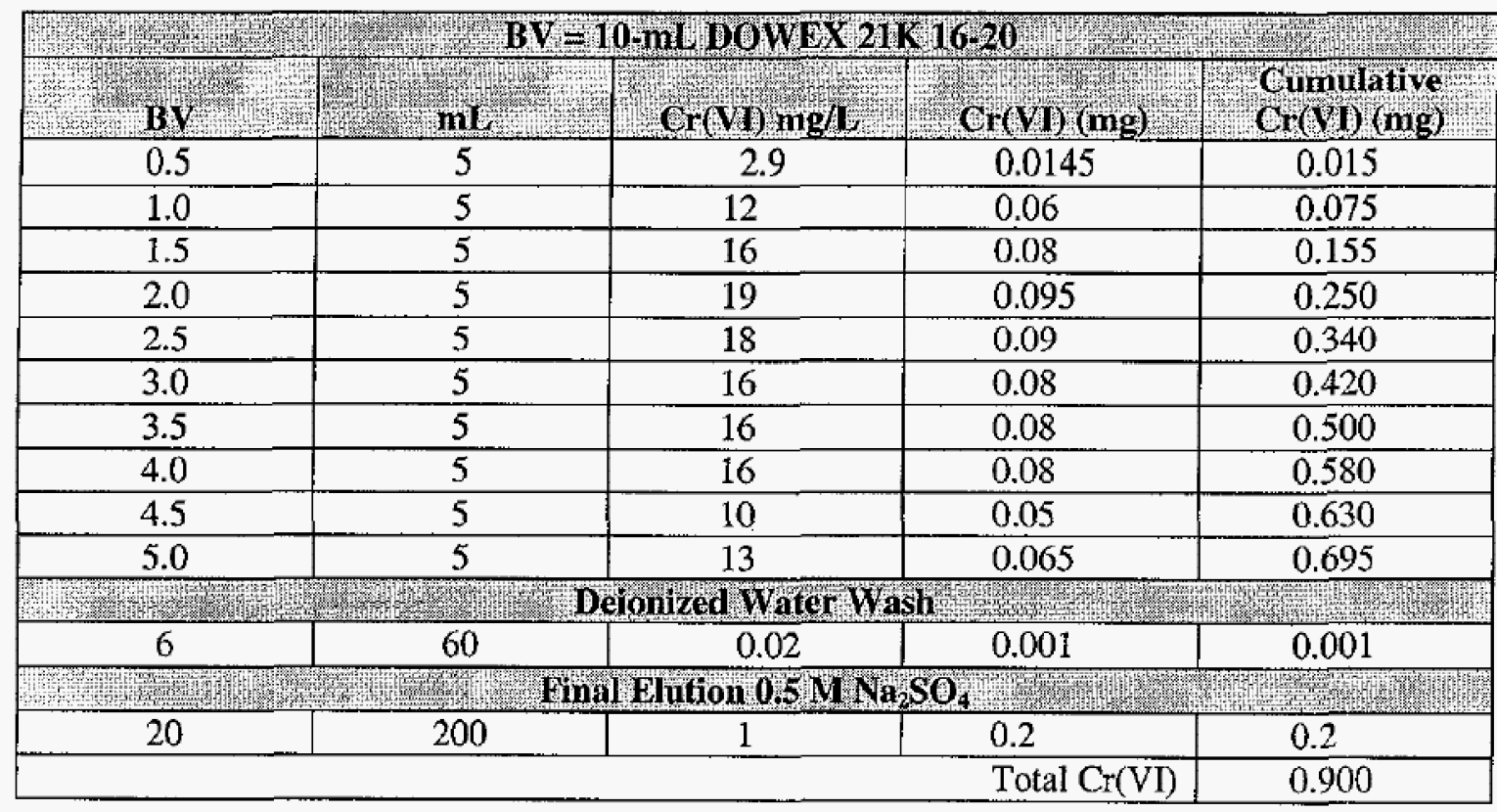


Even though the elution was terminated after $5 \mathrm{BV}$ due to time limitations, this experiment verified that a sodium sulfate was effective on removing $\mathrm{Cr}$ (VI) and therefore is under consideration by the ETF.

\subsubsection{Comparison of Siemens and Sodium Sulfate Regenerated Resin}

Based on the previously described testing, it has been shown that sodium sulfate can regenerate the resin. The next step was to conduct a comparison between sodium sulfate regenerated resin and Siemens regenerated resin. This comparison was conducted by using a $\mathrm{Cr}$ (VI) spiked groundwater sample through single columns.

The groundwater was spiked to $1.25 \mathrm{mg} / \mathrm{L} \mathrm{Cr}(\mathrm{VI})$, calculated, and was verified at a concentration of $1.2 \mathrm{mg} / \mathrm{L}$ using the HACH ${ }^{\mathrm{TM}}$ method 8023 . Although the other ions present in the groundwater were not adjusted, it should be noted that $\mathrm{Cr}$ (VI) was the primary ion of interest and the concentration gave an equivalent of $30 \mathrm{BV}$ to $1 \mathrm{BV}$.

Figure 1 presents the challenge results. Note that even with the adjusted concentration of chrome, neither resin approached breakthrough; defined as $\mathrm{C} / \mathrm{C}_{0}=0.5$. The initial sodium sulfate sample data lagged due to problems with the flow equalizer. The $\mathrm{pH}$ of the effluent was checked during the test and was between 7.0 and 7.5 for both columns. The $x$ axis indicates two jumps at $1500 \mathrm{BV}$ and $6600 \mathrm{BV}$, due to overnight run times.

Some residual chrome in the effluent is expected due to the chrome rich influent and the lack of the sacrificial column. Because of this, the data in Figure 1 shows a positive slope for both the Siemens and sodium sulfate regenerated resin. This leakage is approximately $20 \mathrm{ppb}$ for both resins.

The performance of both resins was better than expected, and as a result the test duration did not exceed the plan because breakthrough was not attained. The test continued until the entire available volume of spiked solution was used. The test duration was comparable to $13,000 \mathrm{BVs}$, or 8 million gal of groundwater.

To present the data in a slightly different way, Figure 2 shows a linear representation of the data to also indicate the $5 \mathrm{ppb}$ limit for the last resin column. 
RPP-RPT-32207, Rev. 0

Figure 1. Siemens and Sodium Sulfate Resin Challenge.

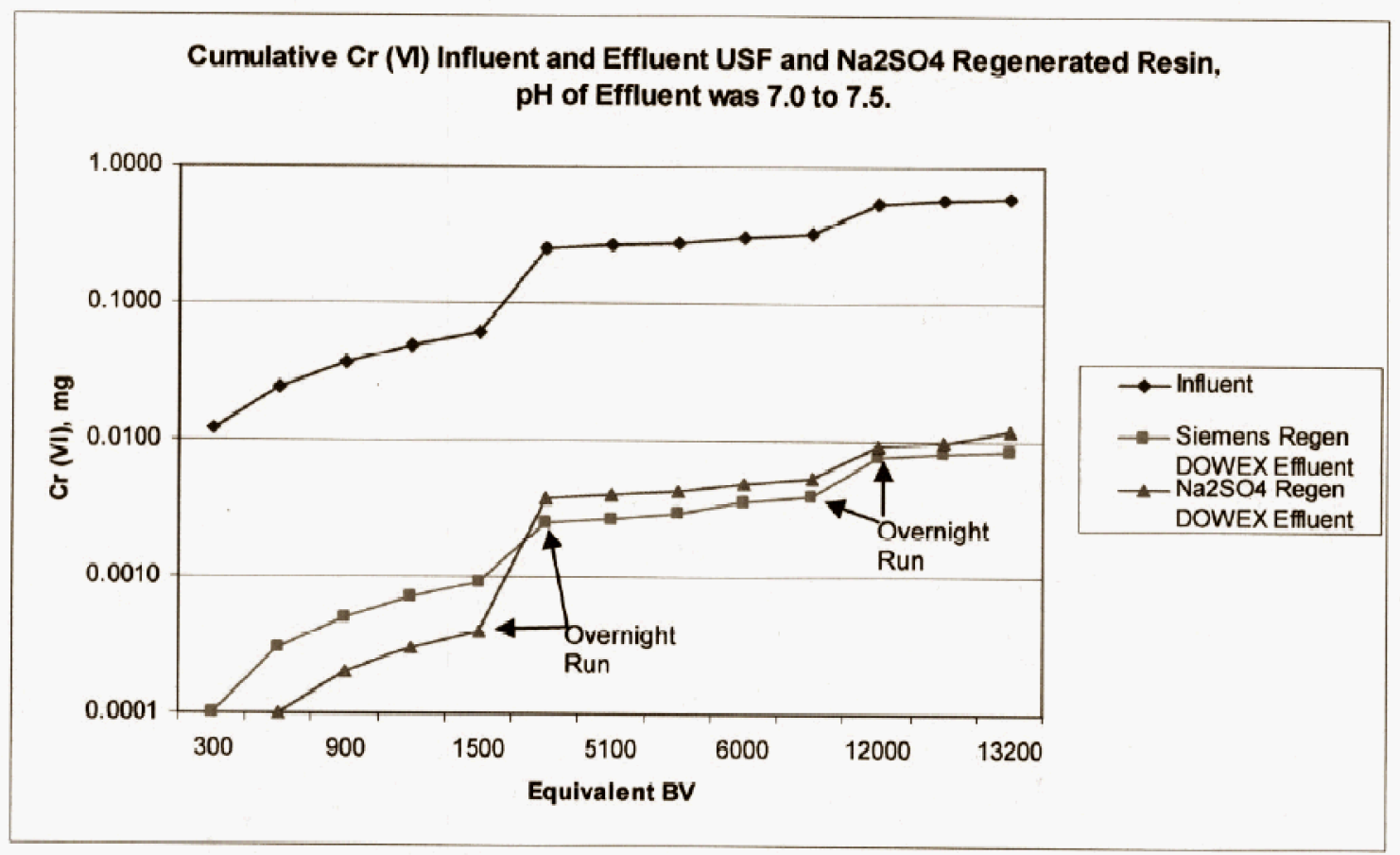

Figure 2. Linear Representation of Challenge Data.

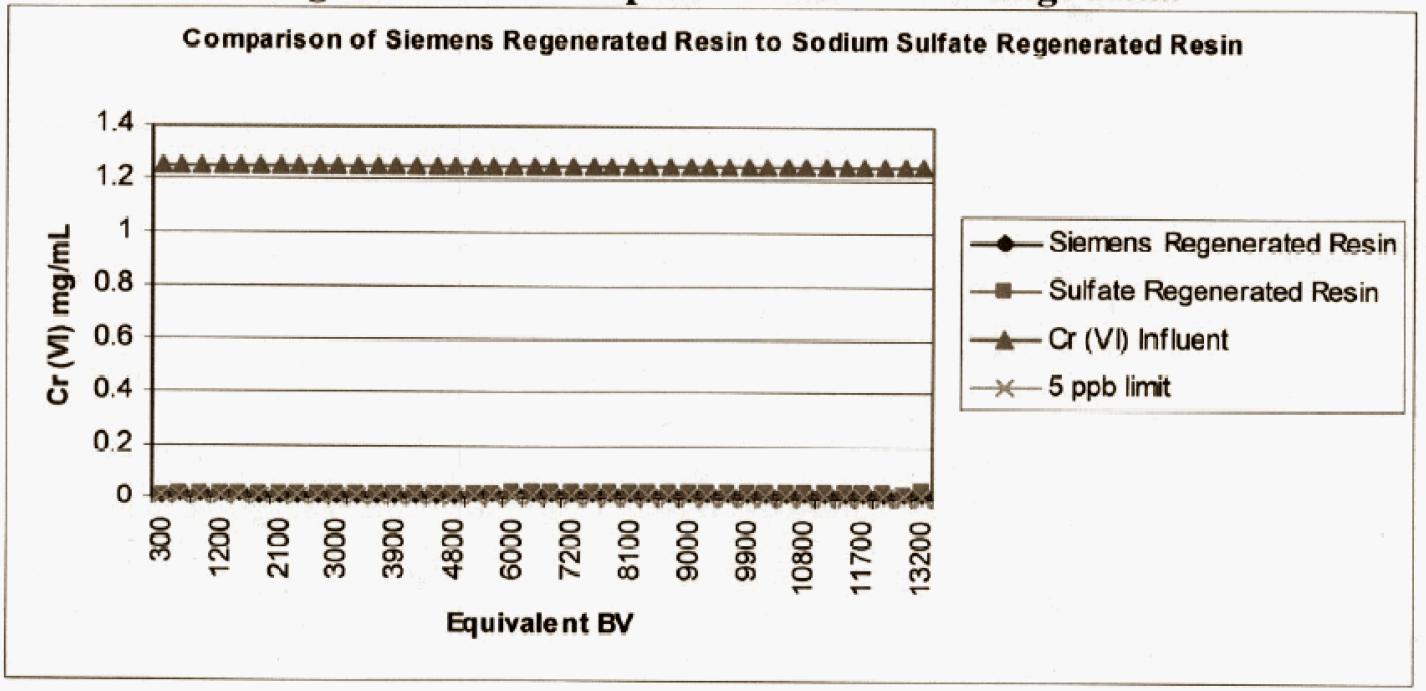

The mass balance for the Siemens and sodium sulfate resin challenge is presented in Table 5 . This data shows that the resins were challenged with $0.58 \mathrm{mg}$ of $\mathrm{Cr}$ (VI) and $0.56 \mathrm{mg}$ was removed for an difference of $3.5 \%$. 
Table 5. Mass Balance of Chrome(VI).

\begin{tabular}{|l|c|c|}
\hline & Siemens Resin & $\begin{array}{c}\text { Sodinm Sulfate } \\
\text { Regenerated Resin }\end{array}$ \\
\hline Total Cr(VI) $=0.58$ & 0.29 & 0.29 \\
\hline Cumulative effluent, mg & 0.0083 & 0.0118 \\
\hline Column wash, mg & 0.252 & 0.286 \\
\hline Sum each column & 0.26 & 0.30 \\
\hline Sum columns & \multicolumn{2}{|c|}{0.56} \\
\hline
\end{tabular}

\subsubsection{Chrome (VI) Residual and Capacity of Sodium Sulfate Regenerated Resin}

A final experiment was carried out with sodium sulfate regenerated resin. The purpose of this test was to estimate the chromate residual and capacity of the sodium sulfate regenerated resin. In this test spent resin was slurred into a $10-\mathrm{mL} \mathrm{BV} \mathrm{column,} \mathrm{and} \mathrm{regeneration} \mathrm{was} \mathrm{carried} \mathrm{out}$ with $0.5 \mathrm{M}$ sodium sulfate. The $\mathrm{Cr}$ (VI) eluted from the column was measured using the $\mathrm{HACH}^{\mathrm{TM}} 8023$ method. The column was washed with $10 \mathrm{BV}$ of DI water and then divided into two 4-mL BV columns with separate pumps. One column was eluted with $0.5 \mathrm{M}$ sodium sulfate and the other with $10 \%$ sodium chloride to determine residual chromate. From the column eluted with sodium chloride, sulfate was determined using the $\mathrm{HACH}^{\mathrm{TM}}$ spectrophotometric sulfate method. This data was used to calculate the resin capacity.

Table 6 shows the results of the $10-\mathrm{mL}$ BV primary elution. Samples were taken every $1.5 \mathrm{BV}$. It should be noted here that the spent resin used had more chromate per unit volume than had been encountered before, a total of $4.35 \mathrm{mg}$ for $10 \mathrm{~mL}$ of resin; all previous testing indicated much lower levels of chromate were on the resin. This suggests that there is a significant variability in the resin utilized in this testing.

Table 6. Sodium Sulfate Elution at 1.5 BV/hour.

\begin{tabular}{|c|c|c|c|c|}
\hline \multicolumn{5}{|c|}{$\quad \mathbf{B V}=10 \mathrm{~mL}$ DOWEX $21 \mathrm{~K} 16-20$} \\
\hline Sample No. & $\mathrm{E}$ & CrND mgd: & CrNI mg & Cumulative \\
\hline 1 & 0.015 & 40 & 0.6 & 0.6 \\
\hline 2 & 0.015 & 50 & 0.75 & 1.35 \\
\hline 3 & 0.015 & 40 & 0.6 & 1.95 \\
\hline 4 & 0.015 & 40 & 0.6 & 2.55 \\
\hline 5 & 0.015 & 40 & 0.6 & 3.15 \\
\hline 6 & 0.015 & 40 & 0.6 & 3.75 \\
\hline 7 & 0.015 & 40 & 0.6 & 4.35 \\
\hline
\end{tabular}

After washing with $10 \mathrm{BV}$ of DI water, the resin was split into two 4-mL BV columns with dedicated pumps. The one column was stripped using sodium sulfate, the other using $10 \%$ sodium chloride. The results of the final strip and the residual meq/ml from the column are presented in Table 7.

The results of this test indicate that the capacity of the sodium sulfate regenerated resin is $1.13 \mathrm{meq} / \mathrm{ml}$; this compares very well to the advertised capacity of $1.2 \mathrm{meq} / \mathrm{ml}$ (Table 8 ). 
RPP-RPT-32207, Rev. 0

Table 7. Residual Chrome(VI) and Sulfate.

\begin{tabular}{|c|c|c|c|c|}
\hline raty & Second Elitition & horone ( M) Strip & Each BV $=4 \mathrm{mi}$ & \\
\hline Eluant & 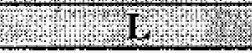 & $\operatorname{Cr}(\mathrm{YI})(\mathrm{mg} / \mathrm{L})$ & Cr (VI) (mg) & meq/mL \\
\hline $0.5 \mathrm{M} \mathrm{Na}_{2} \mathrm{SO}_{4}$ & 0.12 & 0.7 & 0.084 & 0.00081 \\
\hline $10 \% \mathrm{NaCl}$ & 0.12 & 0.8 & 0.096 & 0.00092 \\
\hline
\end{tabular}

Table 8. Resin Capacity Based on a $10 \%$ Sodium Chloride Eluant.

\begin{tabular}{|c|c|ccc|c|}
\hline & & & Resin capacity \\
Eluant & $\mathrm{L}$ & $\mathrm{SO}_{4} \mathrm{mg} / \mathrm{L}$ & $\mathrm{SO}_{4} \mathrm{mg}$ & $(\mathrm{eq} / \mathrm{L})$ \\
\hline $10 \% \mathrm{NaCl}$ & 0.12 & 1800 & 216 & $1.125^{\mathrm{a}}$ \\
\hline
\end{tabular}

a Note that the resin is advertised at having 1.2 eq/ $\mathrm{L}$ capacity.

The results indicate that the residual chromium level on the sodium sulfate resin is $0.00081 \mathrm{meq} / \mathrm{ml}$. This is slightly higher than the current groundwater requirement of $0.00026 \mathrm{meq} / \mathrm{ml}$. As mentioned previously, the resin utilized in this test had significantly higher levels of chromium than any previously seen in the laboratory testing program. A lower chromium residual level would have been possible if the regeneration test would have continued beyond $10 \mathrm{BV}$ (an additional 1 to $2 \mathrm{hr}$ ).

\section{CONCLUSIONS AND RECOMMENDATIONS}

The primary conclusion from the data presented above is that regenerating resin using $0.5 \mathrm{M}$ sodium sulfate is efficacious. It was not within the scope of this study to optimize a process but is merely a collection of data through a series of experiments to show that onsite regeneration is feasible. If desired, further detailed experiments could be carried out to converge on an optimal set of vectors.

The most telling experiment was that of the comparison between the sulfate regenerated resin and the Siemens regenerated resin. Both resins tracked and performed well. It must be remembered that the challenge was not optimal as to the lead, lag, and polish resin columns. The challenge incorporated groundwater and those competing ions that an upfront sacrificial column would (or should) remove. It would be fair to state that if the challenge water was the composition contacted by the lead or lag columns, there probably would not have been leakage exhibited by either regenerated resin.

It is the conclusion and recommendation that onsite regeneration by the ETF is not only feasible but is practicable. It is beyond the scope of this laboratory study to consider economics, but it would seem that onsite regeneration giving faster turnaround, more responsive to the onsite customer, transportation cast savings, etc., would be a positive impact on the budget for the groundwater effort. 
RPP-RPT-32207, Rev. 0

\section{REFERENCES}

Lee, C. C., and S. D. Lin, Ed., 1999, Handbook of Environmental Engineering Calculations, McGraw-Hill, New York, New York.

Letterman, R. D., Ed., 1999, Water Quality and Treatment - A Handbook of Community Water Supplies, $5^{\text {th }}$ Edition, McGraw-Hill, New York, New York.

RPP-PLAN-31627, 2006, "Test Plan for the Regeneration of DOWEX 2IK 16-20 Mesh Anion Spent Resin for the Effluent Treatment Facility," Rev. 0, CH2M HILL Hanford Group, Inc., Richland, Washington.

Schweitzer, P. A., Ed., 1997, Handbook of Separation Techniques for Chemical Engineers, Third Edition, McGraw-Hill, New York, New York.

Weber, W. J., Jr., 1972, Physicochemical Processes for Water Quality Control, Wiley-Interscience, John Wiley \& Sons, Inc., New York, New York. 